выявляет наиболее органичный сюжетологический и нарратологический аспект в изучении чеховской поэтики костюма.

Монография Н. М. Абиевой - многоаспектное, комплексное исследование сюжетообразующей, нарративной, мифопоэтической, интертекстуальной и других функций костюма в поэтике А. П. Чехова. Автор показал, что костюм является полифункциональным явлением поэтики литературного текста.

Светлана Николаевна Черепанова

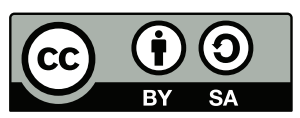

This work can be used in accordance with the Creative Commons BY-SA 4.0 International license terms and conditions (<https://creativecommons.org/licenses/by-sa/4.0/legalcode>). This does not apply to works or elements (such as images or photographs) that are used in the work under a contractual license or exception or limitation to relevant rights.

https://doi.org/10.5817/OS2021-1-12

\title{
По ту сторону рационального
}

Иррациональное в русской культуре. Сборник статей; сост., предисл. Ю. Маннхерц; пер. с англ. Н. Эдельмана. Москва: Новое литературное обозрение, 2020. 264 с. (Серия Studia Europaea). ISBN 978-5-4448-1201-3.

Современные реалии информационной среды вскрывают глубинные пласты иррационального в культуре. Научные открытия последних двух столетий, казалось, должны были укрепить позиции разума в качестве способа освоения действительности, но de facto мы видим, как во всех сферах человеческой деятельности возрастает интерес к «альтернативным формам сознания» [с. 11]. Поэтому сборник статей «Иррациональное в русской культуре», вышедший в 2020 году в издании «НЛО», кажется весьма актуальным. Он предлагает взглянуть на культуру России XIX-XXI веков через призму отношения к иррациональному.

Стереотипы рационального осмысления, сложившиеся в эпоху Просвещения, лишь прикрывали масштабы попыток сверх- или внерационального познания. Эти стереотипы отразились и в языке, закрепив в семантической структуре слов, описывающих иррациональный опыт, оценочные коннотации. В европейской культуре сформировалась бинарная оппозиция «рациональное мышление - аномальное состояние сознания» [с. 12]. По мнению Юлии Маннхерц, составителя сборника, все это во многом затрудняет «нейтральный разговор» [c. 10] об иррациональном. 
Во вступительной статье Юлия Маннхерц определяет актуальные для данного сборника границы понимания «иррационального» и проводит краткий экскурс в историю представлений об этом феномене.

Статья Сергея Штыркова «Юродивый как религиозный тип: Макс Вебер и рациональность безумия» посвящена особенностям социальной рационализации иррационального в юродивом. Автор обращается к типам рациональности Макса Вебера для определения феномена юродивого в религиозном дискурсе. Используя социологический подход для анализа, Сергей Штырков показывает, как, в зависимости от системы ценностных координат, происходят сложные взаимообличительные процессы: в рациональном вскрывается иррациональное и наоборот.

О формах рационализации визионерского опыта, о разном отношении актантов теологического дискурса к иррациональному говорит Ирина Пярт в статье «О видениях во сне и наяву. Визионерство и отношение к нему в русской православной церкви». Она рассматривает случай визионерства солдата Ануфрия Крайнего, учитывая религиозный и церковно-политический контекст XIX века. Ирина Пярт выделяет основные критерии, по которым церковь рассматривает видения солдата относительно православной традиции, а также приводит примеры логического анализа и даже ироничных высказываний священнослужителей по поводу фактов визионерства.

В статье приводятся интересные результаты наблюдений, которые касаются сочетания различных подходов к сверхъестественному со стороны церковных деятелей: подход, связанный с понятиями «прелесть» и «различение духов», и скептический подход, который «оперировал категориями здравого смысла» [c. 71]. И особо ценными кажутся замечания об изменениях при переходе видения из акта бытового в акт социально значимый. В момент, когда (сно-) видение выходит за рамки индивидуального опыта, происходит «столкновение разных дискурсов и позиций» [с. 72]. Это отражается, в частности, на повышении социального статуса визионера и «расширении сакрального пространства» [c.58]. Мы видим, как церковь при этом выступает в качестве регулятора расширения сферы сакрального в контексте православия.

Пейдж Херлингер (ст. «„Чудотворные“ способности „братца“ Иоанна Чурикова с религиозной и светской точек зрения (Санкт-Петербург, 1894-1917)») исследует отношение «трезвенников», светского общества и научного сообщества (врачей) к целительным способностям Иоанна Чурикова, проповедовавшего в начале XX в., а также реакцию православного духовенства на его деятельность. Как утверждает автор, «светская Россия в целом проявляла больше склонности к признанию иррациональных типов веры и лечения, чем церковь» [с. 98]. Врачи и «светское общество» признавали положительное 
влияние «иррациональных верований» на состояние здоровья последователей Чурикова, отрицая при этом «чудеса исцеления». «Трезвенники» же были убеждены в божественной природе исцелений. Со стороны церкви Иоанна Чурикова подвергали различным гонениям, а в 1912 г. был наложен запрет на его проповедническую деятельность. Пейдж Херлингер показывает столкновения всех этих сторон, а также полемику, существовавшую внутри сообществ.

Исследуя дело Александра Квашнина-Самарина, Мария Майофис (ст. «Сумасшествие, слабоумие или социальный невроз? Поэт Александр Квашнин-Самарин») затрагивает ряд важных проблем: человек и власть, человек и бюрократическая машина, норма и отклонение с точки зрения судебной практики XIX в., чиновников, медиков, родственников и самого «безумца». Донос 1837 г. в III Отделение на отставного поручика Квашнина-Самарина за распространение графоманских стихов предосудительного характера определил дальнейшую судьбу бедолаги. Ссылки, тюрьма, сумасшедший дом, а затем государственные выплаты как пострадавшему - все это пришлось пережить горе-графоману. Мария Майофис показывает не только попытки III Отделения «выявить, определить, различить социальные и психические отклонения» [с. 105] Квашнина-Самарина, не только особенности судебно-медицинской практики того времени, но и то, как менялись стратегии поведения «слабоумного», который, в свою очередь, тоже не являлся исключительно жертвой и во многом после того, как он попал под колеса государственной машины, сам провоцировал свои злоключения.

Интересно соотнести это исследование со статьей Екатерины Ходжаевой «„Психиатры в сером“: контроль психически нездоровых граждан со стороны службы участковых уполномоченных Министерства внутренних дел», где рассматриваются особенности работы милиции/полиции и медицинских учреждений с психически нездоровыми гражданами уже в XXI веке, а также роль родственников в этом взаимодействии.

Анализ модели «психологического сопротивления блокадной травме и текстуальные последствия этого сопротивления» [с. 198] на материале личных дневников и художественного творчества жителей блокадного Ленинграда продемонстрировала Полина Барскова в статье «Сверхреальное в блокадном тексте: телеология и репрезентация». Вряд ли можно назвать предложенные модели специфическими для блокадников. А для выводов по текстуальным изменениям, кроме фиксации семантических неологизмов, требуется более обширный материал. Но показанная автором аттракция рационального и иррационального, реального и («ир-») «сверхреального» в попытках пережить ужасы войны однозначно заслуживает более детального и всестороннего исследования. 
Сабина Майер Цур в статье «Достоевский и концепции иррационального в раннем русском психоанализе» показывает, как три исследователя-психоаналитика (Татьяна Розенталь, Николай Осипов и Зигмунд Фрейд) по-разному подходили к исторической личности Достоевского и феномену иррационального, отталкиваясь от его творчества.

Изучению представлений об «иррациональной основе музыкальной метафизики» [с. 166] посвящена статья Ребекки Митчелл «В поисках Орфея: музыка и иррационализм в предреволюционной России (1905-1971)». Музыка воспринималась как «абсолютная иррациональная и соборная форма искусства» [с. 169], которой приписывали важные социальные функции «спасения от разобщенности» [с. 163]. К ней относились как к средству гармонизации «хаоса современной жизни» [с. 163], считалось, что музыка способна «трансформировать саму реальность как физически, так и духовно» [c. 169]. С этим были связаны многочисленные чаяния образованной прослойки населения и возлагались большие надежды на композиторов.

Широкое понимание иррационального, вокруг которого строится весь сборник, позволяет с разных позиций посмотреть на этот феномен (психиатрия, богословие, социология, история, филология и т. д.) и предлагает множество подходов к его изучению. Но подобная размытость дискурса может служить и предметом для критики: сложно решать общую задачу, когда объект исследования неуловим, ввиду своей обширности, невербализованности и культурно-исторически опосредованной когнитивной лакунарности. Это касается общей задачи, что не мешает отдельным статьям быть весьма интересными. Конечно, составитель не пытается осветить все стороны внерационального опыта, да это и невозможно. Данная книга является скорее попыткой «наладить разговор» об иррациональном, преодолеть «языковой и культурный барьеры» при его анализе.

Евгений Николаевич Филиппов

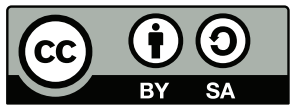

This work can be used in accordance with the Creative Commons BY-SA 4.0 International license terms and conditions (<https://creativecommons.org/licenses/by-sa/4.0/legalcode>). This does not apply to works or elements (such as images or photographs) that are used in the work under a contractual license or exception or limitation to relevant rights. 